\title{
Rice Straw for Use in Dairy Heifer Rations
}

\author{
G. A. NADER, Farm Advisor, University of California Cooperative Extension Farm \\ Advisor, Yuba-Sutter Counties; and P. H. ROBINSON, UC Cooperative Extension \\ Specialist, Department of Animal Science, University of California, Davis.
}

Recent increases in feed costs have prompted dairy owners and nutritionists to explore new ways to optimize rations for growing heifers. In free-choice rations, dairy operators often use forages and wheat straw to provide bulk and limit feed intake. The use of rice straw, produced in high quantities in the Sacramento and northern San Joaquin Valleys, has been part of our research on dairy heifer rations since 2004. In our studies we have learned a lot about how to make rice straw a valuable feed in heifer rations as well as ways to overcome the main hurdle that has made it hard to use: incorporation of long rice straw stems into Total Mixed Ration (TMR) mixers requires substantially longer mixing times and often damages mixing equipment, necessitating shutdowns and repairs.

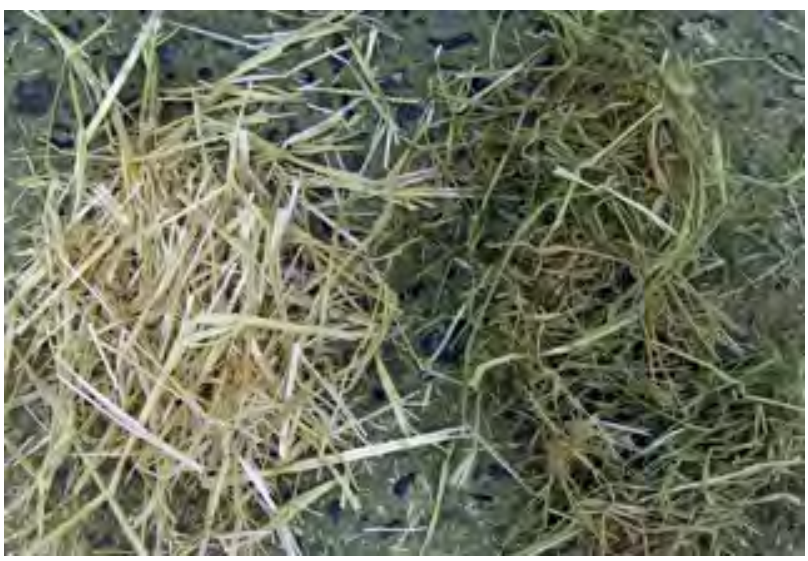

Figure 1. The traditional straw used in dairy heifer rations, wheat straw (left), is shown alongside cutter-baled rice straw (right).

California is the second-largest rice producing state in the United States, and the area north of Sacramento is one of the most highly concentrated rice growing regions in the country. Rice straw, a co-product of rice harvest, is mostly incorporated into soil by disking to improve soil quality and add nitrogen, which reduces the amount of nitrogen fertilizer input required for the following year's crop, thus reducing overall costs. It is estimated that 3 to 5 percent of the area's rice straw is baled for various uses, including cattle forage, erosion control, and straw bale construction. Many dairy owners now realize that rice straw can be used in rations for replacement heifer diets to provide dry matter and bulk to slow ruminal rate of passage when combined with byproduct feeds. The key for success is to purchase rice straw that has been baled with a cutter baler set to cut it in 3- to 5-inch lengths that allow it to be added to TMR mixers without chopping. 
The rice and rice straw harvest runs from August to November. Straw that is baled within 10 days of harvest may qualify as a feedstuff, but longer times in the field inevitably lead to bleaching and excessive drying that compromise fiber quality. Rice straw can be baled more quickly through early September, mostly because there are more hours of daylight and generally less rain than later in the year.

\section{Harvest and Cutting Options}

Rice straw is produced by a variety of methods, including

1. Straw walker harvester, baling the windrows for a long-stem product.

2. Rotary style harvester, which, depending on the make of the harvester and its ground speed during harvest, can shred the straw to varying degrees. The harvested straw windrows can then be baled.

3. Flail chopping chops the dried windrows of straw to reduce their stem length before baling.

4. Cutter baler is a baler equipped with a cutter apparatus that slices the straw into 3- to 5-inch lengths.

5. Swathing usually means cutting the plant near ground level and then baling to remove all of the straw.

Rice straw baling and stacking costs in 2008 ranged from $\$ 25$ to $\$ 40$ per ton, while baling with a cutter or flail chopping before baling added an additional $\$ 5$ to $\$ 9$ per ton. This added expense of cutting straw is worthwhile at baling as it reduces the chopping expense of making the straw into acceptable feed later at the dairy.

Historically, the major problem associated with feeding rice straw to cattle, especially as unprocessed, long-stem bales (method 1 , above) is that it still needs to be chopped prior to feeding. The high silica content of rice straw makes this a slow and energy-intensive process that creates dust and dulls chopper knives.

Dairy rice straw feeding demonstrations have shown that it is critical that rice straw be cutter baled (method 3, above) if it is to be used in heifer rations. This approach greatly improves its mixing performance and eliminates selective consumption of the TMR by cattle, which can defeat the purpose of feeding a nutritionally balanced TMR. Demonstrations have shown that rice straw baled with less than 12 percent moisture using a cutter baler could be fed at 2 to $4 \mathrm{lb}$ per head per day when combined with other feeds in a TMR mixer. Rice straw that has not been sliced or chopped to reduce its stem length to 3 to 5 inches should not be purchased by a dairy unless they plan to chop it before mixing. Longer straw lengths (i.e., over 5 inches) result in unevenly mixed TMR, longer mixing times, and a greater risk that mixer parts will break when long straw wraps around mechanical shafts. More information on the results from our dairy rice straw feeding demonstrations are available online (for 2008) at www.carrb.com/08rpt/Nader\%20 RU5\%2008.pdf and for 2007 at www.carb. com/07rpt/2007\%20Nader\%20RU-5.pdf.

Many rice growers already own flail choppers and are not interested in purchasing a cutter baler. However, our dairy demonstrations with flail-chopped rice straw showed that, when fed at 2 to $3 \mathrm{lb}$ per head per day, the straw did not mix completely into the TMR, but instead formed "balls" ( figure 3) that were not eaten by the heifers ( figure 4). At $5 \mathrm{lb}$ per head per day, the flail-chopped straw increased mixing times. If rice growers wait until the windrowed straw has reached 10 percent moisture before they flail chop and bale it, they may be able to reduce these problems. Figures 3 and 4 illustrate the problems of "balling", which enables animals to sort against rice straw. 


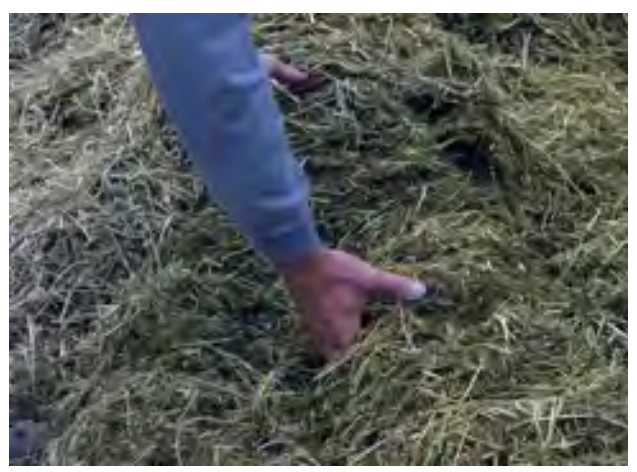

Figure 2. Cutter-baled rice straw that has been evenly mixed into the Total Mixed Ration (TMR).

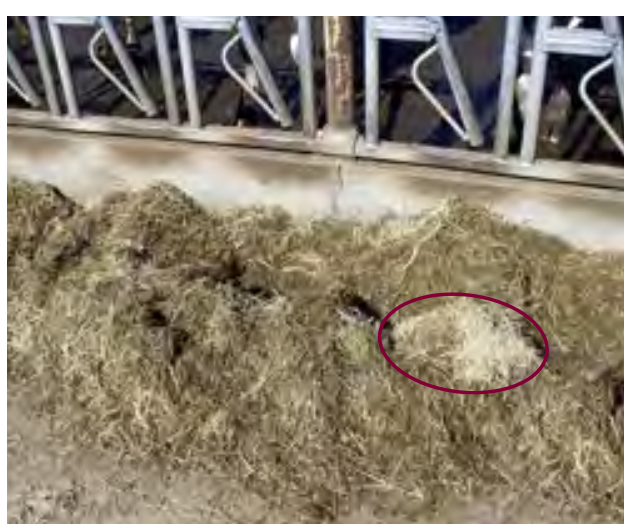

Figure 3. Flail-chopped rice straw causes uneven mixing.

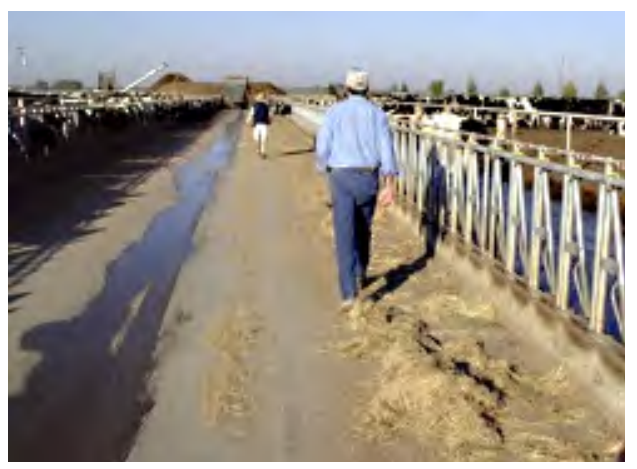

Figure 4. Flail-chopped rice straw in a TMR remains uneaten after 24 hours.

\section{Nutrient value}

The nutrient value of rice straw is much lower than that of alfalfa hay, making it is generally inappropriate in rations of lactating cows. However the nutrient levels and feeding values of individual rice straws do vary considerably. California rice straws generally run about 67 percent $( \pm 5 \%)$ neutral detergent fiber, 50 percent $( \pm 3 \%)$ acid detergent fiber (ADF), and 5 percent $( \pm 1 \%)$ crude protein $(\mathrm{CP})$, with all values determined on a dry matter (DM) basis. Factors that impact rice straw nutritional value include plant maturity at harvest (e.g., grain head moisture), the soil in which the rice is grown, rice variety, and nitrogen fertilizer management. Extensive UC research has indicated that a rice straw with an $\mathrm{ADF}$ value below 50 percent (DM basis) can be considered to be feed quality for replacement heifers.

The range of nutrient values for two years of sampling (2002 and 2003) of 77 stacks of baled rice straw in Northern California are in Table 1. These data demonstrate the wide variability in the nutrient content of rice straw.
Figures 5 and 6 provide a sample of the degree of variation in nutritional value in 133 stacks of Northern California rice straw sampled during 2002, 2003, and 2008. The quality of rice straw was different each year, and in 2008 the $\mathrm{CP}$ and $\mathrm{ADF}$ levels both were much lower than in the earlier years. These data demonstrate that the nutrient quality of the straw can vary significantly from year to year. 
Table 1. Nutrient content range of California rice straw, based on samples taken from bale stacks over two years (2002 and 2003).

\begin{tabular}{|l|c|c|c|c|c|c|c|c|c|c|}
\hline \multirow{2}{*}{ Content level } & \multicolumn{7}{|c|}{ Nutrient component* } \\
\cline { 2 - 10 } & DM & OM & Fat & CP & ADICP & NDF & dNDF & ADF & TDN \\
Average & 93.93 & 83.59 & 1.94 & 4.81 & 12.60 & 67.57 & 38.33 & 49.49 & 40.90 \\
Maximum & 95.30 & 87.50 & 2.90 & 7.00 & 19.10 & 72.50 & 47.20 & 55.00 & 50.50 \\
Minimum & 91.70 & 76.50 & 0.90 & 3.30 & 7.60 & 60.00 & 29.30 & 43.60 & 31.10 \\
\hline
\end{tabular}

\begin{tabular}{|c|c|c|c|c|c|c|c|c|c|c|c|}
\hline & \multicolumn{11}{|c|}{ Chemical element $^{\dagger}$} \\
\hline & $\mathrm{Ca}$ & $\mathbf{P}$ & $\mathrm{Mg}$ & K & $\mathbf{S}$ & $\mathrm{Na}$ & $\mathrm{Cl}$ & $\mathrm{Cu}$ & Fe & $\mathrm{Zn}$ & Mo \\
\hline & \multicolumn{7}{|c|}{ - } & \multicolumn{4}{|c|}{ 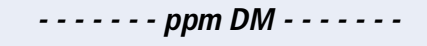 } \\
\hline Average & 0.30 & 0.095 & 0.199 & 1.738 & 0.076 & 0.15 & 0.52 & 4.3 & 396 & 28 & 0.844 \\
\hline Maximum & 0.50 & 0.170 & 0.295 & 2.700 & 0.150 & 0.50 & 1.20 & 13.0 & 3400 & 60 & 3.700 \\
\hline Minimum & 0.19 & 0.051 & 0.120 & 1.100 & 0.037 & 0.01 & 0.097 & 1.5 & 130 & 13 & 0.250 \\
\hline
\end{tabular}

*Nutrients: $\mathrm{DM}=$ dry matter, $\mathrm{OM}$ = organic matter, $\mathrm{CP}$ = crude protein, $\mathrm{ADICP}$ = acid detergent insoluble $\mathrm{CP}$ (an estimate of the indigestible $\mathrm{CP}$ fraction), $\mathrm{NDF}=$ neutral detergent fiber, $\mathrm{dNDF}=$ digestible NDF (an estimate of the digestible NDF fraction), ADF $=$ acid detergent fiber, $T D N=$ total digestible nutrients tChemical elements: $\mathrm{Ca}=$ calcium, $\mathrm{P}=$ phosphorus, $\mathrm{Mg}=$ magnesium, $\mathrm{K}=$ potassium, $\mathrm{S}=$ sulfur, $\mathrm{Na}=$ sodium, $\mathrm{Cl}=$ chlorine, $\mathrm{Cu}=$ copper, $\mathrm{Fe}=$ iron, $\mathrm{Zn}=$ zinc Mo $=$ molybdenum

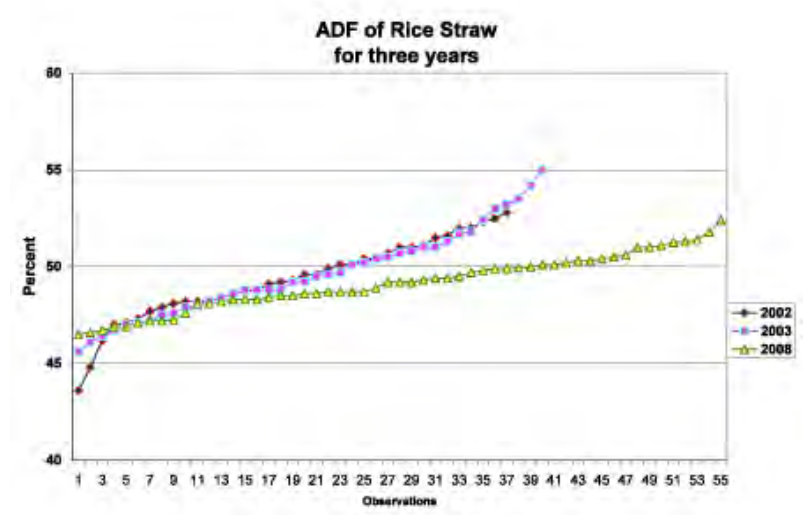

Figure 5. Acid detergent fiber (ADF) levels in 2002, 2003 and 2008.

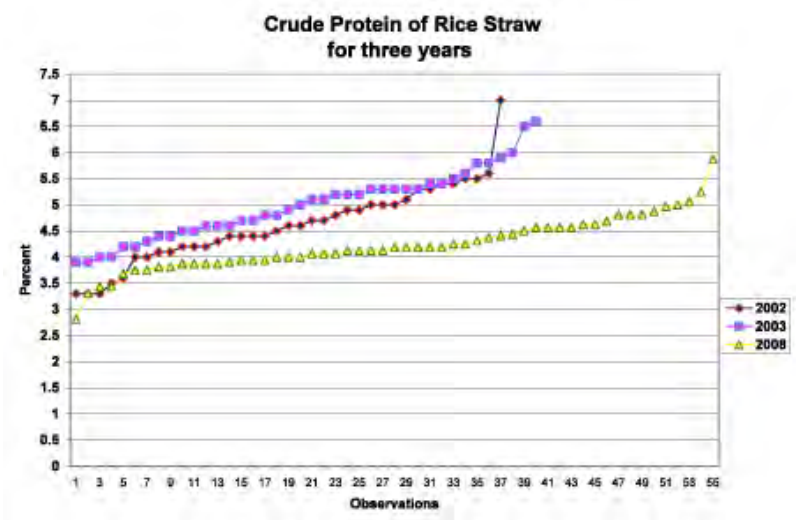

Figure 6. Crude protein (CP) levels in 2002, 2003 and 2008.

\section{Getting Started}

If you are interested in using rice straw in your heifer TMRs, you can find suppliers online at www.ricestrawmarket.org.

It is important to recognize that rice straw producers seldom bale straw in anticipation of sales, but most accept orders from July to September for delivery after mid-September. Ask for delivery to the dairy in the fall, since many rice producers store their straw on the rice levees where rain-soaked soil can make later shipments difficult. 


\section{For More Information}

You will find related information in these titles and in other publications, slide sets, CD-ROMs, and videos from UC ANR: Feeding Rice Straw to Cattle, Publication 8079

Dairy Nutritionists' Roles in Nutrient Use: Recommendations for Feed Nutrients Records Analyses, Publication 8278

Use of Feed Inventory Records to Reduce Nutrient Loading at Dairy Operations: Producer Options, Publication 8277

To order these products, visit our online catalog at http://anrcatalog.ucdavis.edu. You can also place orders by mail, phone, or FAX, or request a printed catalog of publications, slide sets, CD-ROMs, and videos from

University of California

Agriculture and Natural Resources

Communication Services

6701 San Pablo Avenue, 2nd Floor

Oakland, California 94608-1239

Telephone: (800) 994-8849 or (510) 642-2431, FAX: (510) 643-5470

e-mail inquiries: danrcs@ucdavis.edu

An electronic version of this publication is available on the ANR

Communication Services website at http://anrcatalog.ucdavis.edu.

Publication 8392

ISBN-13: 978-1-60107-667-0

\section{UCER}

REVIEWED This publication has been anonymously peer reviewed for technical accuracy by University of California scientists and other qualified professionals. This review process was managed by the ANR Associate Editor for Animal, Avian, and Veterinary Sciences.

(C) 2010 by The Regents of the University of California

Agriculture and Natural Resources.

All rights reserved.

The University of California prohibits discrimination or harassment of any person on the basis of race, color, national origin, religion, sex, gender identity, pregnancy (including childbirth, and medical conditions related to pregnancy or childbirth), physical or mental disability, medical condition (cancer-related or genetic characteristics), ancestry, marital status, age, sexual orientation, citizenship, or service in the uniformed services (as defined by the Uniformed Services Employment and Reemployment Rights Act of 1994: service in the uniformed services includes membership, application for membership, performance of service, application for service, or obligation for service in the uniformed services) in any of its programs or activities.

University policy also prohibits reprisal or retaliation against any person in any of its programs or activities for making a complaint of discrimination or sexual harassment or for using or participating in the investigation or resolution process of any such complaint.

University policy is intended to be consistent with the provisions of applicable State and Federal laws.

Inquiries regarding the University's nondiscrimination policies may be directed to the Affirmative Action/Equal Opportunity Director, University of California, Agriculture and Natural Resources, 1111 Franklin Street, $6^{\text {th }}$ Floor, Oakland, CA 94607, (510) 987-0096. For information about obtaining this publication, call (800) 9948849. For downloading information, call (530) 754-3927.

To simplify information, trade names of products have been used. No endorsement of named or illustrated products is intended, nor is criticism implied of similar products that are not mentioned or illustrated.

web-6/10-WJC/RW 